\title{
Aplikasi Sistem Pakar untuk Mendiagnosa Virus Covid-19 pada Manusia Berbasis Web Menggunakan Metode Forward Chaining
}

\author{
Sari Noorlima Yanti ${ }^{1}$, Endah Budiyati ${ }^{2}$ \\ ${ }^{1}$ Program Studi Teknik Informatika, Univsitas Gunadarma, Depok, Indonesia \\ ${ }^{2}$ Program Studi Psikologi, Univsitas Gunadarma, Depok, Indonesia \\ e-mail: 1'sariny@staff.gunadarma.ac.id, ${ }^{2}$ endah_b@ @staff.gunadarma.ac.id
}

Submitted Date: April $25^{\text {th }}, 2020$

Revised Date: October 03 ${ }^{\text {rd }}, 2020$
Reviewed Date: May $11^{\text {th }}, 2020$

Accepted Date: January $04^{\text {th }}, 2021$

\begin{abstract}
The Covid-19 virus is currently a pandemic in the world community. This virus spreads through human-to-human contact with many media. Human lungs are organs in the human body that are vulnerable to the Covid-19 virus attack. This virus attacks through stages that are predicted to take several days. The stages from a person making contact with a sufferer of the Covid-19 virus until he is tested positive are different. Some of the factors that play a role in the attack of the spread of this virus are in addition to a person's immune weakness such as age, immunity, obesity, medical history, hygiene and the supplements a person takes. One of the ways to deal with the Covid-19 pandemic is to provide accurate information on how to prevent the spread of this virus. This information is expected to provide input to everyone in order to prevent infection. An important role in a person's life is to maintain cleanliness in daily activities to prevent contracting this virus, which has many deaths due to contracting the Covid-19 Virus. A person's knowledge and little information will be affected if they fail to maintain their health from the Covid-19 Virus attack. This situation requires an expert who is well aware of the virus and all its symptoms. This research can help us to diagnose someone's health and anticipate having a risk of contracting the Covid-19 virus by designing and implementing it. The Covid-19 Expert System was designed on a web basis using the programming languages PHP and MySQL. In this expert system, several questions are asked. After all the questions are answered, the results of the diagnosis and suggestions can appear that can help diagnose the Covid-19 Virus attack.
\end{abstract}

Keywords: Covid-19 Virus; Expert System Application; PHP Programming; MySQL Database.

\begin{abstract}
Abstrak
Virus Covid-19 saat ini menjadi pandemi di masyarakat dunia. Virus ini menyebar melalui kontak antar manusia ke manusia lain dengan banyak media. Paru-paru manusia adalah organ tubuh manusia yang rentan terhadap serangan virus Covid-19. Serangan virus ini melalui tahapan yang diprediksi memakan waktu bebarapa hari. Tahapan dari seorang melakukan kontak dengan penderita virus covid-19 sampai dinyatakan positif berbeda. Beberapa factor yang berperan dalam serangan penyebaran virus ini adalah di samping kelemahan imunitas seseorang seperti usia, kekebalan tubuh, obesitas, riwayat kesehatan, kebersihan dan suplemen yang dikonsumsi seseorang. Salah satu cara menanggulangi pandemi covid-19 ini adalah memberikan informasi yang tepat bagaimana mencegah penyebaran virus ini. Informasi tersebut diharapkan dapat memberi masukan kepada semua orang agar menjaga terjadinya penularan. Peran penting dalam kehidupan seseorang menjaga kebersihan dalam aktifitas sehari-hari menjaga tidak tertular virus ini yang banyak kematian akibat tertular oleh Virus Covid-19. Pengetahuan dan informasi sedikit oleh seseorang akan terkena dampak jika lalai menjaga kesehatan dari serangan Virus Covid-19. Situasi ini dibutuhkan seorang pakar yang sangat mengetahui virus dan semua bentuk gejala penyakitnya. Penelitian ini dapat membantu kita untuk mendiagnosa kesehatan seseorang dan mengantisipasi jika mempunyai resiko terkena virus Covid-19 dengan merancang dan mengimplementasikan. Sistem Pakar Covid-19 dirancang berbasis web menggunakan bahasa pemrograman PHP dan MySQL. Pada sistem pakar ini diajukan beberapa pertanyaan. Setelah semua pertanyaan terjawab, maka tampak hasil diagnosa beserta saran yang dapat membantu mendiagnosa dari serangan Virus Covid-19.
\end{abstract}


Kata Kunci: Virus Covid-19; Aplikasi Sistem Pakar; Pemrograman PHP; Database MySQL

\section{Pendahuluan}

Seiring berkembangnya teknologi saat ini sangat pesat banyak munculnya ide-ide baru yang dapat membantu manusia dalam mendapatkan suatu informasi. Namun, dengan banyaknya informasi yang tersedia dapat menyebabkan masyarakat menginginkan fasilitas yang lebih memadai dan efisien terutama dengan adanya teknologi sistem pakar berbasis web. Sehingga dikembangkan pula suatu teknologi yang mampu mengadopsi cara berfikir manusia yaitu Artificial Intelligence (AI) atau kecerdasan buatan.

Sistem pakar merupakan suatu bidang ilmu menggunakan kecerdasan buatan. Cara kerja sistem pakar adalah menggabungkan pengetahuan dan pencarian database untuk memecahkan masalah. Sistem pakar dibentuk menyerupai keahlian manusia yang diterjemahkan dalam bentuk sistem. Kemampuan tersebut dapat membantu sehingga dapat digunakan oleh orang banyak orang. Sistem pakar memiliki beberapa kategori yaitu kategori pengembangan dan kategori pengembangan besar dari sistem pakar adalah dibidang diagnosis.

Covid-19 merupakan salah satu virus yang berbahaya dan membunuh nomor satu didunia saat ini tidak dapat ditangani dengan baik. Aplikasi web ini bertujuan membantu menginformasikan bukan berarti menghilangkan atau menggantikan peran dari seorang pakar, ahli, setidaknya dapat memasyarakatkan pengetahuan para pakar virus Corona melalui sistem ini, secara langsung pasien dapat mengetahui dan melihat bagaimana cara mengetahui penderita Virus Covid-19 berdasarkan gejala dan jenis penyakit yang diderita oleh pasien.

Berdasarkan hal di atas tersebut dibuatlah system mendiagnosa penderita Virus Covid-19. Menjadi sangat penting guna memberikan pengetahuan bagi masyarakat menyangkut dunia kesehatan, serta memberikan pengetahuan pentingnya kesehatan bagi masyarakat awam.

\section{Metodologi \\ Virus Covid-19}

Virus Corona atau severe acute respiratory syndrome coronavirus 2 merupakan jenis virus menyerang fungsi pernapasan manusia. Covid-19 adalah sebutan jika terinfeksi virus ini. Penderita virus ini bisa menganggu fungsi sistem pernapasan, pneumonia akut dan sampai kematian.

Severe acute respiratory syndrome coronavirus 2 (SARS-CoV-2) dikenal di dunia dengan nama virus Corona merupakan corona virus jenis baru yang menginfeksi manusia. Semua manusia dapat terinfeksi virus ini bayi, anak-anak, orang dewasa, lansia, ibu hamil dan ibu menyusui bisa terkena virus ini (Huang, 2020).

Kasus infeksi virus COVID-19 pertama kali diidentifikasi di kota Wuhan Republik Rakyat Cina.
Kasus ini ditemukan pada akhir Desember Tahun 2019. Penyebaran dan penularan virus ini cepat sampai menyebar ke wilayah lain di Cina sampai ke beberapa negara, termasuk Indonesia. Keadaan ini membuat beberapa negara menerapkan kebijakan dengan memberlakukan lockdown dalam upaya menghentikan penyebaran virus Corona (Wang, 2020).

Virus corona secara umum meyerang sistem pernapasan pada manusia.Virus ini tidak hanya menyebabkan infeksi pernapasan seperti flu saja. Infeksi pernapasan berat akibat virus corona ini dan infeksi paru-paru atau pneumonia. Virus ini juga membuat gejala seperti pada kasus virus SARS atau Severe Acute Respiratory Syndrome dan MERS atauMiddle-East Respiratory Syndrome (Coronavirus, 2020).

Berikut ini adalah gejala pasien virus Covid-19 menurut badan kesehatan dunia (WHO). Pasien COVID-19 mengalami gangguan pernapasan juga mengalami gejala lain seperti:

1. Mual maupun diare. Organisasi Kesehatan Dunia (WHO) melaporkan bahwa ada sekitar lima persen pasien dari seluruh dunia merasakan mual. Tiga persen pasien di China mengalami diare berdasarkan data yang dipublikasikan The Lancet. Pada umumnya para pasien mengalami gejala demam di awal terjangkit. Peneitian belum menemkan bagaimana virus bisa memengaruhi pencernaan. Gejala ini termasuk tidak biasa sebab hanya sebagian kecil pasien yang merasakannya (World Health Organization, 2020).

2. Kemampuan indra perasa dan penciuman mengalami kerusakan. Informasi yang diterima publik dihebohkan dengan sejumlah pasien COVID-19 mengatakan mereka merasakan hilangnya kemampuan indra perasa dan penciuman. Gejala ini tidak umum terjadi karena menurut survei melibatkan 59 pasien di Italia, hanya 19 persen yang mengalami. Pasien yang kehilangan salah satu indra 34 persen. Para ahli belum menemukan jawaban yang pasti namun menurut perkiraan yang dilaporkan LiveScience virus ini menginfeksi lapisan dalam rongga hidung. Sel pendeteksi bau sulit mengidentifikasi udara yang masuk saat area tersebut peraradang. Penciuman dan perasa sangat mempunyai ketergantungan satu sama lain. Ketika salah satunya indra tidak berfungsi kemungkinan yang lainya tidak berfungsi. Penelitian lanjut masih dibutuhkan untuk menemukan penyebab sebenarnya.

3. Perasaan tidak enak, berdasarkan informasi WHO gejala COVID-19 tidak hanya gejala fisik tetapi juga psikis. Banyak pasien mengeluhkan perasaan tidak enak. Keluhan tersebut seperti perasaan gelisah hingga tidak nyaman. Berdasarkan jurnal dari StatPearls berjudul "Features, Evaluation, and 
Treatment Coronavirus (COVID-19)", gejala seperti ini tidak banyak dilaporkan. Perasaan tidak enak terjadi karena rasa takut, kesepian, stres, dan gelisah selama proses karantina. Informasi mengenai virus corona saat ini mampu membuat seseorang mengalami gangguan kecemasan. (WHO, 2019)

4. Berdasarkan data dari Centers for Disease Control and Prevention (CDC) penderita mengalami rasa kebingungan. Kebingungan ini menjadi gejala atau bahkan tanda peringatan seseorang menderita COVID-19. Berikut laporan para medis dari Amerika Serikat, Austria, Italia, Jerman, dan Tiongkok melalui New York Times, pasien ada yang mengalami kesulitan memberi tahu nama mereka sendiri. Gejala lain adalah kurang responsif terhadap dokter dan seperti oranga linglung. Gejala ini cukup berbahaya karena seseorang bisa kebingungan mungkin terjadi sesuatu pada otaknya. Virus corona berhasil memengaruhi organ terpenting seperti otak sangat membahayakan. Gejala kebingungan seperti ini dapat terjadi rumit untuk mencari sebabnya. Kebingungan itu timbul karena aliran oksigen ke otak kurang. Para tenaga medis harus ekstra perhatian jika pasien mengalami kondisi seperti ini karena mereka berisiko mengalami kejang-kejang (World Health Organization, 2020).

5. Sakit kepala, Ketika sedang flu, kita memang sering merasa sakit kepala atau pusing. Gejala tersebut termasuk gejala yang tidak biasa pada COVID-19. Berdasarkan studi The Lancet, delapan persen pasien yang mengalami ini. Sebagian orang bisa mengalami sakit kepala ini terjadi sebagai efek dari gejala demam. Suhu tubuh yang panas bisa membuat kita merasakan sakit kepala atau bahkan pening.

6. Rasa nyeri pada otot atau nyeri pada otot bisa menandakan berbagai penyakit. Presentasenya sekitar 14 persen para penderita COVID-19 yang mengalaminya menurut laporan dari WHO. Kondisi tersebut merupakan indikasi awal serangan infeksi sedang terjadi. Jika merasakan gejala seperti ini dan dibarengi demam serta batuk kering istirahat dan lakukan isolasi mandiri (World Health Organization, 2020).

7. Hidung berair, Walaupun mirip seperti flu, COVID-19 sangat jarang menimbulkan gejala hidung berair hingga pilek. Organisasi Kesehatan Dunia WHO mengatakan yang mengalami kondisi tersebut sekitar lima persen pasien saja. Penderita umumnya mengalami gejala merasakan sakit tenggorokan dan hidung tersumbat (World Health Organization, 2020).

\section{Sistem Pakar}

Pembuatan suatu sistem pakar oleh seorang pengembang software harus bekerja sama dengan seorang pakar. Pengembangan sistem memerlukan tahapan pertanyaan berguna untuk mengumpulkan dasar-dasar pengetahuan sang pakar. Seluruh informasi yang diperoleh dimasukan kedalam basis pengetahuan sistem pakar berbentuk fakta dan aturan. Kemudian pengembang membangun suatu mesin inferensi (inference engine) yang merupakan pembuat keputusan dalam sistem pakar. Informasi yang dikumpulkan dari user dengan menjawab pertanyaan yang diberikan oleh sistem dan membandingkan informasi ini dengan basis pengatuhuan, kemudian memutuskan apa yang harus diinformasikan ke pengguna berdasarkan data atau informasi yang telah diberikan (Arhami, 2005).

Sistem ini adalah cabang dari kecerdasan buatan yang membuat penggunaannya secara luas pengetahuan penyelesaian masalah tingkat manusia pakar merupakan definisi system pakar (Arhami, 2005). Penggunaan aplikasi computer untuk digunakan menyelesaikan masalah sesuai yang dipikirkan para pakar merupakan cara kerja system pakar. Definis para pakar adalah para ahli yang memiliki kemampuan menyelesaikan masalah yang tidak dapat diselesaikan oleh orang awam (Kusrini, 2008). Sistem pakar memungkinkan suatu system yang dirancang bertujuan untuk membuat keputusan yang cepat sesuai pendapat pakar.

Diciptakan berbentuk sistem komputer menampilkan pengetahuan manusia yang ahli dalam bentuk heuristic. Sistem pakar merupakan sistem yang mengambil pengetahuan manusia ke dalam sistem komputer yang dirancang memodelkan kemampuan menyelesaikan masalah seperti kemampuan seorang pakar (Kusrini, 2008).

\section{Konsep Dasar Sistem Pakar}

Sistem pakar pada konsep dasar mengandung keahlian, ahli, aturan, pengalihan keahlian inferensi, dan kemampuan menjelaskan. Keahlian merupakan kelebihan penguasaan pengetahuan dibidang tertentu yang diperoleh dari pelatihan, membaca, atau pengalaman (Turban, Aronson, \& Liang, 2005). Pengalihan keahlian dari para ahli komputer untuk dialihkan ke orang lain yang bukan ahli merupakan tujuan utama dari sistem pakar. Proses ini membutuhkan empat aktivitas, yaitu: tambahan pengetahuan (terdiri dari para ahli atau sumber-sumber lainnya), representasi pengetahuan (ke komputer), inferensi pengetahuan, dan pengalihan pengetahuan ke user. Pengetahuan yang disimpan dikomputer disebut dengan nama basis pengetahuan. Ada dua tipe basis pengetahuan, yaitu: fakta dan prosedur (biasanya berupa aturan). Kemampuan untuk menalar merupakan kemampuan yang harus dimiliki oleh suatu sistem pakar. Semua data keahlian-keahlian sudah tersimpan dalam database computer sebaai basis pengetahuan yang dibaca oleh program komputer. Aplikasi komputer tersebut harus di rancang agar dapat membentuk inferensi. Proses inferensi dapat dikemas dalam bentuk mesin inferensi (inference engine). 


\section{Struktur Sistem Pakar}

Sistem pakar memiliki 2 komponen 2 utama terdiri dari basis pengetahuan dan mesin inferensi. Database pengetahuan disimpan di dalam komputer yang dipakai sebagai basis data program atau aplikasi komputer di mana basis data ini diambil dari pengetahuan pakar (Arhami, 2005).

Sistem pakar dibentuk berdasarkan 2 bagian utama (McLeon, 2008):

1. Informasi pengembangan dipergunakan sebagai memasukkan pengetahuan kedalam suatu sistem pakar.

2. Informasi konsultasi dipergunakan yang bukan pakar berguna mendapatkan pengetahuan pakar.

Menurut Arhami, komponen-komponen sistem pakar adalah seperti di bawah ini (Arhami, 2005):

1. Antar muka merupakan teknik yang dipergunakan antara pengguna dan sistem untuk saling berkomunikasi.

2. Basis data pengetahuan memiliki formulasi, pemahaman menyelesaikan penyelesaian masalah. Sistem ini dibentuk terdiri dari elemen fakta dan aturan

3. Database pengetahuan adalah gabungan transformasi keahlian membantu penyelesaian masalah ke komputer melalui sumber pengetahuan.

4. Mesin komputer mempunyai pola pikir dan penalaran para pakar dalam menyelesaikan masalah.

5. Workplace adalah sekumpulan memori kerja yang dipergunakan menyimpan hasil-hasil dan kesimpulan.

6. Bagian penjelasan merupakan komponen tambahan menambah kemampuan sistem pakar. Sistem pakar perlu ada perbaikan untuk menunjang kinerja dan kemampuan untuk menganalisis peningkatan kinerjanya dan kemampuan.

Dua bagian utama dalam system pakar adalah lingkungan pengembangan (development environment) dan lingkungan konsultasi (consultation environment) (Turban, 205).

\section{Forward Chaining}

Metode inferensi ranut sangat pas dipakai menangani masalah peramalan/prognosis dan pengendalian/controlling (Riley, 2005). Pengetahuan dalam Kaidah penelitian produksi direpresentasikan dalam bentuk (Honggo wibowo, 2009):

JIKA [antecedent] MAKA [konsekuen]

JIKA [kondisi] MAKA [aksi]

JIKA [premis] MAKA [konklusi]

Pengaturan kaidah produksi dibagi menjadi kaidah derajat pertama dan kaidah meta. Peraturan pertama sebagai bagian konklusinya bukan menjadi premis bagi kaidah setelahnya. Kaidah meta adalah kaidah yang konklusinya merupakan premis bagi kaidah sebelumnya (Honggo wibowo, 2009).

Penggabungan pengetahuan dilakukan dengan cara mengelompokan pengetahuan tentang diagnosa gejala pasien virus covid-19 yang dihimpun dari banyak sumber. Informasi pengetahuan berdasarkan analisa lewat informasi internet ke dalam sebuah daftar gejala dan kondisi pasien guna mempermudah proses pencarian solusi. Pola pencocokan antara daftar gejala dan Kondisi pasien ini sebagai pola dimasukan pengguna dan basis pengetahuan. Pembuatan daftar gejala dan kondisi pasien sebagai basis pengetahuan untuk membuat suatu kesimpulan menjadi kesimpulan: Keterangan dari gejala penderita:

G01 : Demam (suhu tubuh di atas 38 derajat Celsius)

G02 : Batuk Tidak Berdahak

G03 : Infeksi Saluran Pernapasan (Pneumonia)

G04 : Kelelahan

G05 : Pegal-Pegal

G06 : Tidak Nafsu Makan

G07 : Kehilangan Indra Penciuman dan Rasa

G08 : Keadaan Bingung

G09 : Sakit Kepala dan Pusing (Stroke Ringan)

G10 : Kejang-Kejang

G11 : Diare dan Mual (Gastrointestinal)

G12 : Rasa Kedinginan dan Nyeri Otot

G13 : Kulit terasa terbakar / Tersengat Listrik

Keterangan dari Kondisi Pasien :

K01 : Usia Lanjut (umur > 50 Tahun)

K02 : Balita (umur $<5$ Tahun)

K03 : Riwayat Penyakit Kronis

K04 : Golongan Darah (O=kebal dan A, B, $\mathrm{AB}=$ Rentan

K05 : Wanita Hamil

K06 : Perokok

\section{Analisa Permasalahan Perancangan}

Berdasrkan hasil analisis permasalahan pada sistem pemeriksaan awal gejala pasien Covid-19, dapat diketahui bahwa masih adanya sistem yang belum menggunakan komputerisasi. Namun semuanya berjalan secara manual. Pada proses pemeriksaan awal Covid-19 pada manusia ini memerlukan sistem yang dapat membantu user dalam membantun menjawab keluhan yang dialami oleh user sebelum user pergi rumah sakit dan membantu user dalam memberikan informasi bagaimana caranya mengajaga kesehatan. Sistem yang diperlukan adalah pemeriksaan gejala awal penderita Covid-19 dengan kondisi pasien saat kejadian. Dalam sistem pemeriksaan kesehatan secara online, dan dibuat sebuah sistem pakar yang dapat menggantikan posisi dokter dalam memeriksa keluhankeluhan yang dialamai oleh user. User juga diberikan informasi cara menyembuhkan dan memberikan solusi untuk mengkonsumsi makan yang sehat. Dalam sistem ini user juga dapat melihat secara lengkap data-data 
tentang Covid-19, dan bagaimana cara mengatasinya didalam aplikasi web sistem pakar ini.

\section{Rancangan Tampilan Aplikasi}

Tampilan aplikasi dari sistem pakar dirancang merupakan alat komunikasi antara sistem dengan pengguna yang menggunakan use case diagram, Flowchart, Struktur Navigasi, dan Diagram Entity Relationship.

\section{Use Case Diagram}

Use Case Diagram memberikan interaksi antara sistem dan juga pengguna, menggambarkan fungsionalitas sistem yang harus dipenuhi dari pandangan pemakai. Diagram ini terdapat actor/user merupakan pengguna sedangkan sistemnnya merupakan aplikasi persilangan yang dihubungkan dengan garis directed asociation.

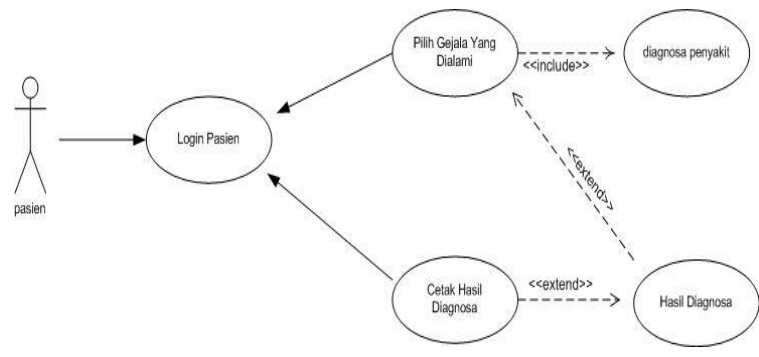

Gambar 1. Diagram UseCase Sistem Pakar Covid-19

\section{Flowchart}

Proses yang terjadi pada sistem secara sederhana dapat dijelaskan, dimana proses konsultasi pengguna dihadapkan dengan pernyataan dan pertanyaan tersebut diurutkan dari urutan gejala yang ada di database tersebut. Pengguna harus menjawab pertanyaan yang ada pada sistem pakar ini dengan pilihan YA dan TIDAK, jika pilih TIDAK maka gejala dihapus dari database sedangkan jika pilih YA maka gejala disimpan. Sistem ini membaca gejala yang dimasukan oleh pengguna yang disesuaikan dengan basis pengetahuan, apabila gejala sudah terpenuhi maka tampil hasil, dan jika tidak maka proses ke tampil pertanyaan lagi.

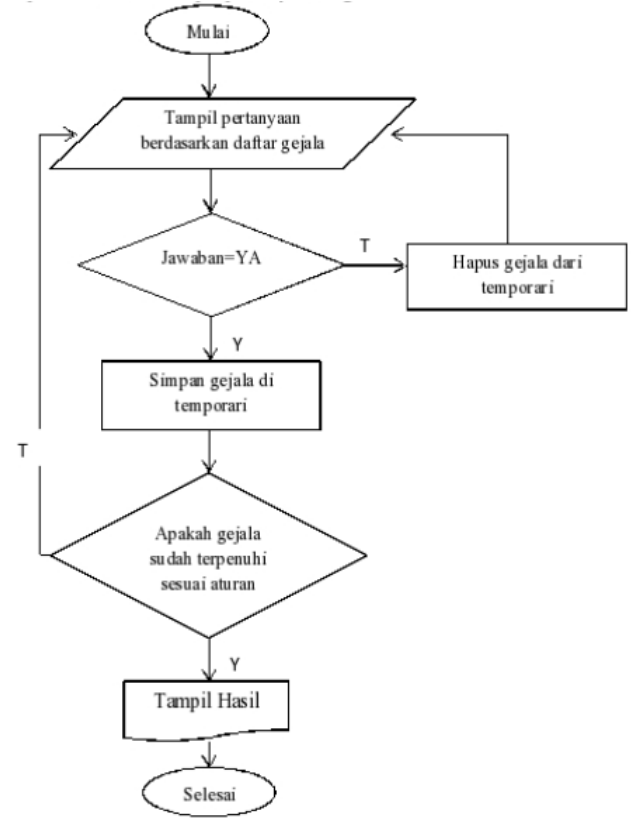

Gambar 2. Diagram Flowchart Sistem Pakar Covid-19

\section{Struktur Navigasi}

Aplikasi sistem pakar diagnosa penyakit covid-19 pertama menentukan menentukan struktur navigasi. Pada aplikasi ini menggunakan sturktur navigasi hirarki. Penggunaan struktur navigasi hirarki dipilih aplikasi tertata dengan rapi. Struktur hirarki ini tidak membuat kerancuan dalam memberikan informasi yang muncul di halaman web. Gambar 3 menunjukan struktur navigasi alur jalannya aplikasi dalam aplikasi ini.

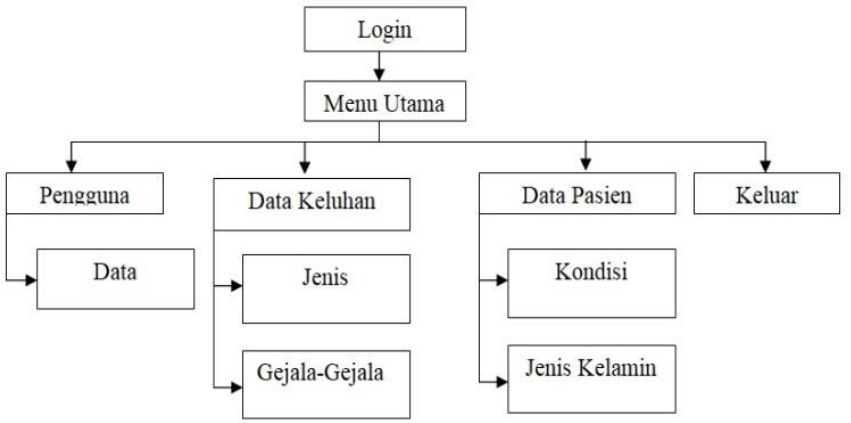

Gambar 3 Navigasi Sistem Pakar Covid-19

\section{Rancangan Database}

MySQL merupakan program database server sebagai tempat penyimpanan dan mengolah data (Sutarman, 2005). Database MySQL adalah salah satu software sistem manajemen database (DBMS) Structured Query Language (SQL) yang bersifat opensource. 

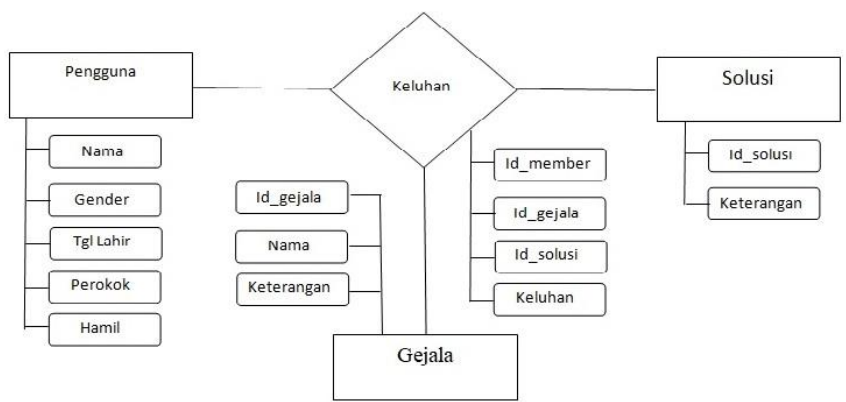

Gambar 4. Rancangan Diagram ERD Sistem Pakar Covid-19

\section{Penerapan Metode Forward Chaining}

Pada penelitian ini menggunakan metode forward chaining dengan teknik representasi Rule Based Reasoning. Teknik forward chaining dengan memasukan sekumpulan fakta kedalam memori kerja, selanjurtnya mencocokkan fakta dengan bagian IF dari rules IF-THEN. Jika fakta yang sesuai bagian IF, maka rule akan dijalankan. Jika ada rule dijalankan, maka fakta baru (bagian THEN) dimasukan ke database. Pencocokkan dimulai dari rule paling teratas. Satu rule hanya boleh di jalankan sekali. Tahapan pencocokkan akab berhenti jika tidak ada lagi rule yang jalankan atau sudah mencapai goal atau tidak ada aturan dengan premis cocok dengan fakta.

Mesin inferensi digunakan pada penelitian ini untuk mendiagnosis penyakit covid-19. Mesin inferensi ini menggunakan metode forward chaining untuk mendiagnosis penyakit tersebut setelah menerima gejala-gejala yang di input pengguna. Semua jawaban pengguna dilakukan pencarian nilai kesamaan dengan nilai gejala suatu penyakit yang ada di dalam knowledge-based, sehingga diproleh nilai kesesuaian berdasarkan frekuensi dan intensitas database gejala pada penyakit covid-19.

Sistem pemeriksaan terhadap covid-19 masih sangat terbatas karena belum akurat. Proses pemeriksaan pasien juga secara menggunakan alat pemeriksaat yang belum canggih

Pasien pendrita covid-19 datang ke rumah sakit untuk bertanya keluhan-keluhan yang dialami oleh pasien kemudian pasien diperiksa secara fisik oleh dokter.

Jika ternyata pasien mempunyai tanda-tanda adanya penyakit covid-19 maka dokter melakukan karantina. Penceegah resiko penyebaran virus yang diderita oleh pasien dilakukan sambil menunggu penderita sembuh secara mandiri.

Sampai saat ini belum ada vaksin atau obat yang secara penelitian ilmiah dapat menyembuhkan pasien dari tertular virus covid-19.
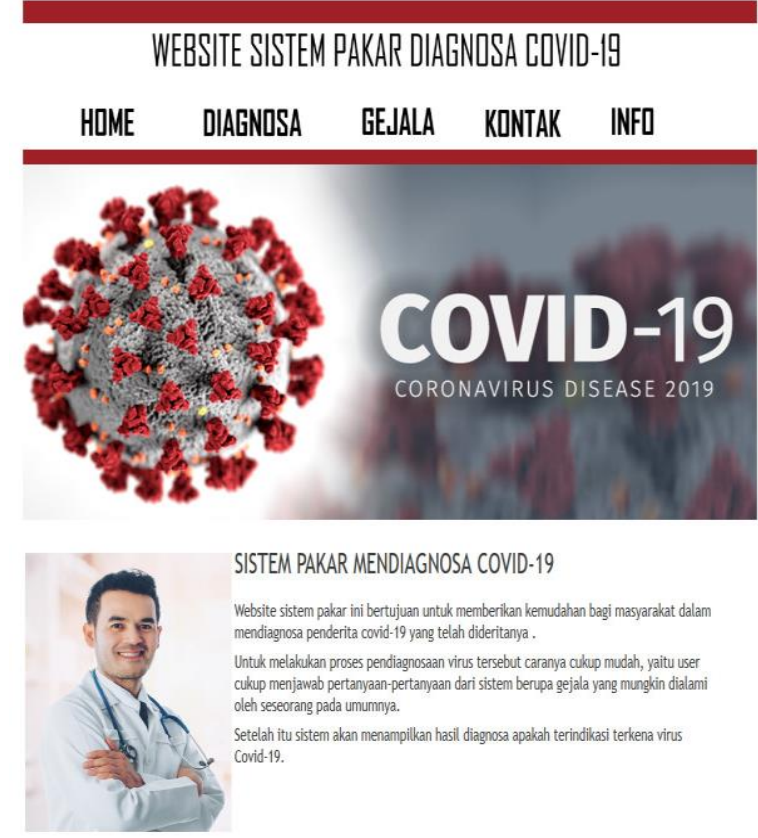

SISTEM PAKAR MENDIAGNOSA COVID-18

Copyright 02020 Bendahbudiyanti

Gambar 5. Tampilan Halaman Utama
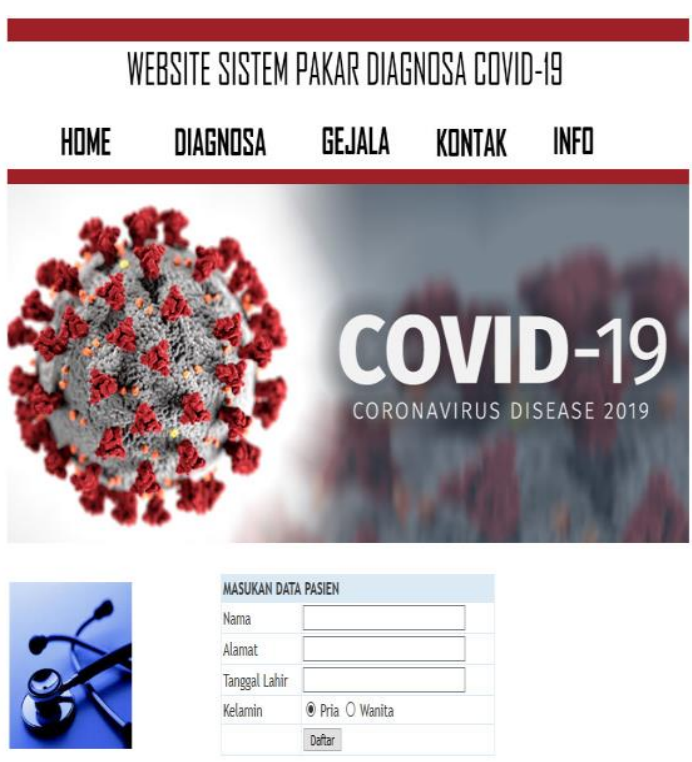

\section{SISTEM PAGAR MEDOHGNOSA COND-}

Gambar 6 Tampilan Halaman Input Pengguna 

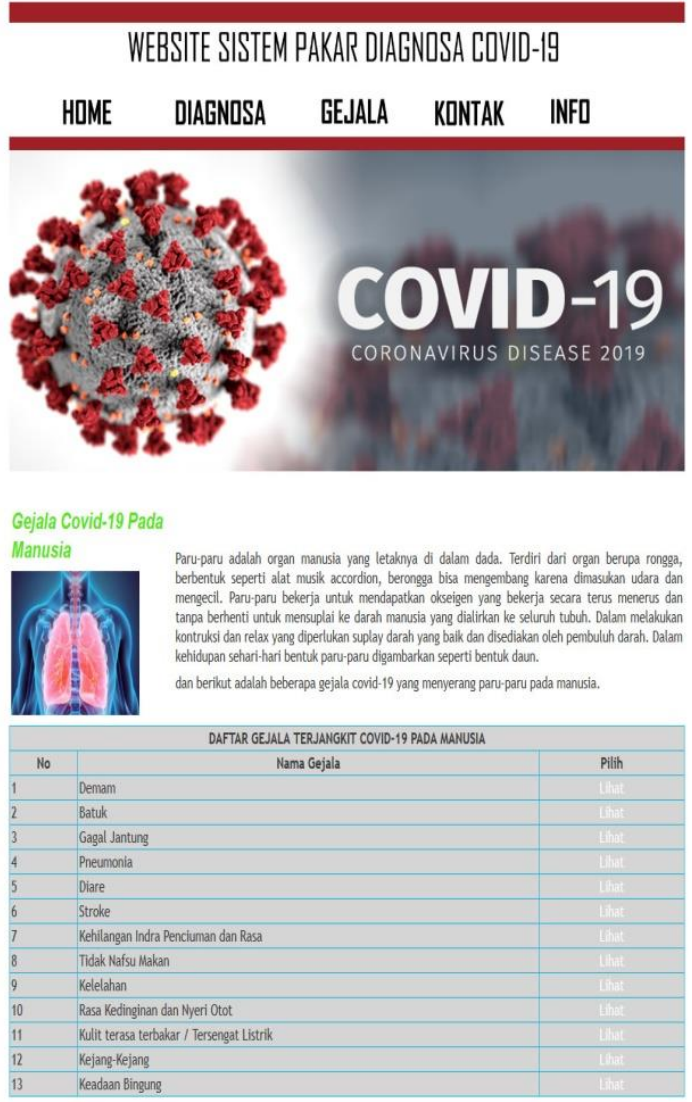

Gambar 7 Tampilan Awal Diagnosa

\section{Pengujian Hasil Analisa}

Setelah pengguna menjawab dari beberapa pertanyaan yang telah disediakan oleh sistem dengan jawaban "IYA" atau "TIDAK" maka gejala yang diderita mucul. Selanjutnya sistem ini mengumpulkan data dan dikirimkan langsung ke halaman hasil analisa.

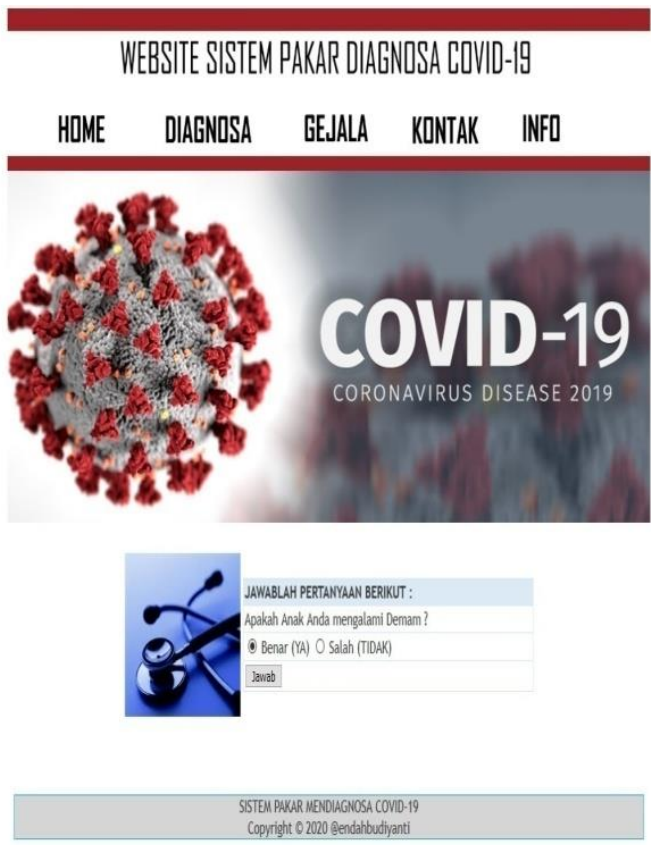

Gambar 8 Tampilan Input Data Pasien
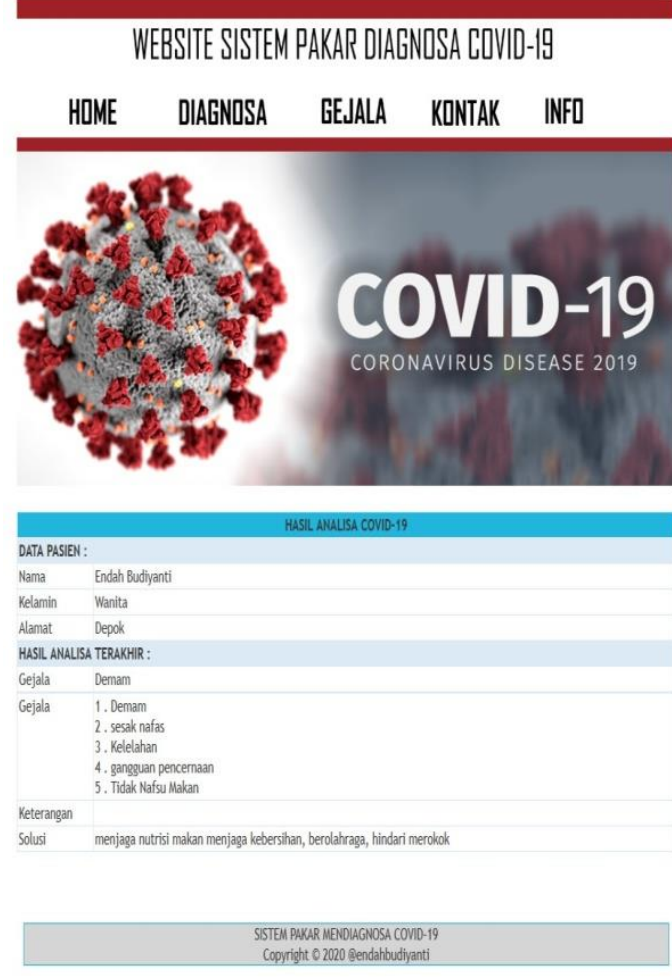

Gambar 9. Tampilan Hasil Diagnosa

\section{Kesimpulan}

Berdasarkan keseluruhan yang dapat diuraikan dalam penelitian ilmiah ini, peneliti dapat menarik kesimpulan, bahwa secara keseluruhan sistem pakar covid-19 yang dibuat sudah cukup mudah digunakan. Hasil representase yang berasal dari penilaian aplikasi secara keseluruhan dapat membantu mendiagnosa awal paseien Covid-19. Sistem ini hanya mampu mendiagnosa awal pasien Covid-19 yang terjadi pada manusia dengan memberi solusi sementara untuk mengatasinya. Sistem ini dapat dikembangkan lagi menjadi lebih informative seiring dengan perkembangan informasi yang di hasilkan tentang Covid-19.

\section{Saran}

Informasi yang berkembang berdasarkan temuan seperti pasien penderita Covid-19 tidak mengalami gejala seperti umumnya membuat system ini harus kembangkan databasenya. Berdasarkan informasi tersebut membuat kesulitan mendeteksi pasien penderita Covid-19. Sepertinya virus ini terus bermutasi mengikuti kondisi manusia saat ini.

\section{Referensi}

Arhami, M. (2005). Konsep dasar sistem pakar. Yogyakarta: Andi. 
Coronavirus, N. (2020). Centers for Disease Control and Prevention. Novel Coronavirus.

Honggo wibowo, A. (2009). Sistem Pakar Diagnosa Penyakit Tanaman Padi Berbasis Web dengan Forward Chaining dan Backward Chaining. TELKOMNIA, No. 3, Vol. 7.

Huang. (2020). Clinical features of patients infected with 2019 novel coronavirus in Wuhan. The Lancet, 6736(20), , pp. 1-10.

Kusrini. (2008). Aplikasi Sistem Pakar. Yogyakarta: Andi Offset.

McLeon. (2008). Sistem Informasi Manajemen. Jakarta: Salemba Empat.

Riley, G. \&. (2005). Expert Systems: Principles and Programming.

Sutarman. (2005). Membangun Aplikasi Web dengan PHP dan MySQL. Yogyakarta: Grahallmu.

Turban, E., Aronson, J., \& Liang, T.-P. (2005). Decision Support Systems and Intelligent Systems (Sistem pendukung keputusan dan sistem cerdas). Yogyakarta: Andi Yogyakarta.

Wang. (2020). A Novel Coronavirus Outbreak of Global Health Concern. The Lancet, pp. 1-4.

World Health Organization. (2020). Novel Coronavirus. New York: Novel Coronavirus. 